\title{
ECOLOGY OF BAT SPECIES IN THE ARID REGION OF THE DAURIAN STEPPE AT THE PEAK OF DROUGHT
}

\author{
Yury A. BazhenoviD \\ Institute of Natural Resources, Ecology and Cryology, Siberian Branch of RAS, Russia \\ e-mail:uran238@ngs.ru
}

Received: 15.06.2020. Revised: 23.11.2020. Accepted: 24.11.2020.

\begin{abstract}
Bats (Chiroptera) are the least studied group of mammals in the Daurian steppe (Inner Asia: Mongolia, Russia and China). We surveyed the bat fauna of the Daurian steppe and some ecological features of bat species in 2008-2019. We recorded six bat species in this region, of which Vespertilio murinus, V. sinensis and Myotis davidii are the most abundant. Myotis davidii tended to hide in the rocks near fresh water sources. Unlike Vespertilio, M. davidii avoided settling in human constructions. Vespertilio species can live farther from water sources compared to $M$. davidii. The sex ratio of collected adult $V$. murinus, $V$. sinensis, $M$. davidii was female-based. This indicates that these species do not hibernate in the Daurian steppe region. Our results show the important role of the studied region for these migratory bat species, as it is a breeding territory. At the beginning of the XXI century, many lakes and rivers dried up partially or completely in Dauria. In the Russian part of the Daurian steppe, we observed an increase in the $V$. sinensis population and a decrease in the populations of M. petax and M. davidii. We speculate that the change in the bat community is a consequence of the reduction in the number of water bodies in Dauria, especially in the Mongolian part (Dornod aimag).
\end{abstract}

Key words: climate change, dry period, Mongolia, range extension, sex ratio

\section{Introduction}

Bats (Chiroptera) are an important group of mammals because of their multiple functional roles in ecosystems (Boyles et al., 2011; Kunz et al., 2011). Bats are slow-breeding animals and therefore relatively vulnerable to abrupt environmental changes (IUCN, 2020). They have an excellent mobility and can respond quickly to environmental changes (Norberg \& Rayner, 1987; Luo et al., 2019). Climate change has altered the distribution and ecology of many species including bats (Lundy et al., 2010; Sherwin et al., 2013; Wu, 2016). One possible mechanism for the change in geographic distribution of bats is that climate change could cause a reduced available fresh water source in arid ecosystems (Sherwin et al., 2013; Razgour et al., 2018). In these ecosystems, bat activity and diversity concentrates near water bodies and associated vegetation (Adams, 2010; Korine et al., 2016; Amorim et al., 2018). For example, in Central Mongolia, even suboptimal water sources such as water containers for livestock are used by bats under conditions of a lack of natural water sources (Nyambayar et al., 2010).

The Daurian steppe is located on the northern periphery of Inner Asia. It is a globally important arid, ecological region due to the high biodiversity. The «Landscapes of Dauria» (in Russian and Mongolian) is a transboundary serial World Heritage since 2017. The Daurian steppe is a region ecologically strongly depending on climate changes. Long-term changes in precipitation of the Daurian steppe are cyclic (Obyazov, 2012). The lake level and river flows directly depend on precipitation. Many water bodies of the Daurian steppe were drying up in the early XXI century (Sosnina \& Kurganovich, 2015; Golyatina et al., 2018). For example, the largest lakes and many small lakes in Transbaikalia Torey had dried up completely by 2017 . The Daurian ecosystem is adapted to cyclical changes in humidity. Landscapes changed from wetland to dry steppe and in wet phases the reverse processes took place (Kirilyuk et al., 2012).

In the Daurian steppe, the ecological features of bat fauna are poorly studied (Botvinkin, 2002). To date, six bat species were known, including Myotis davidii (Peters, 1869), M. petax Hollister, 1912, Plecotus ognevi Kishida, 1927, Vespertilio sinensis Peters, 1880, V. murinus Linnaeus, 1758, and Eptesicus nilssonii (Keyserling \& Blasius, 1839) (Rosina \& Kirilyuk, 2000; Botvinkin, 2002; Bazhenov, 2013; Monhnast, 2014; Ariunbold, 2016). Four of them (M. davidii, M. petax, P. ognevi, V. sinensis) are listed in the Red Data Book of Zabaikalsky Krai (2012) (Russia) as «needed protection» or as «data deficient». Vespertilio sinensis is listed in the Mongolian Red Book (2013). None of them is considered as threatened species by the International Union for Conservation of Nature (IUCN).

The aim of this study is to summarise data on the bat species distribution in the Daurian steppe, relative abundance of bats and sex ratios of then, and exam- 
ine the effect of climate change (drought for several years) on the occurrence and distribution of bats in the Daurian steppe. Despite an increase in interest in the relationship between range expansions and climatic change (Lundy et al., 2010; Wu, 2016), the effects of climatic factors on bat distribution remain rarely studied. The study of bat populations in Dauria is important for understanding the modern climate change effects on threatened species in arid ecosystems of Central Asia.

\section{Material and Methods}

The study was conducted in the Daurian steppe situated at the juncture of the Mongolian, Russian and Chinese state borders, in the northern part of Inner Asia. The Daurian steppe has a mid-temperate, semiarid and continental monsoon climate. The average annual rainfall is $250-350 \mathrm{~mm}$.

The largest amount of data has been obtained in the Daursky State Nature Reserve and its buffer zone (Zabaikalsky Krai, Russia), Mongol Daguur Strictly Protected Area (Dornod Aimag, Mongolia), and Hulun Lake Reserve (Inner Mongolia, China).

We caught bats during the warm season (from May to August). We did not find any bats between September and April. We searched for bats in vari- ous potential shelters and caught them by hand, tweezers or net. In addition, we sampled bats in ground-level mist nets. Mist nets $(4 \times 10 \mathrm{~m}$, mesh size $=17 \mathrm{~mm}$ ) were placed near previously known or supposed bat shelters or near water sources. Bats were collected, identified for age and gender, measured, and weighed. All animals were released then at the capture sites. In Russia and Mongolia, some bats were tagged with numbered bands on their right forearms (Russian ornithological bands with the inscription «Moscow №» and special wing bands with the inscription «Russia №», produced by Aranea, Poland) for future tracking. Band diameters are 2.9 $\mathrm{mm}$ for Myotis and $4.2 \mathrm{~mm}$ for Vespertilio.

In 2008-2019, we sampled 21 sites in the Daurian steppe (Fig. 1). Each site included one to five sampled localities. We tested the relationship between the more common bat species and important elements of the environment in 500$\mathrm{m}$ buffer around the bat locations. We used 31 locations of recorded bats (each site from Table 1 contains one to three locations with the same or other environment elements). We assessed whether the sex ratio of bats varied from 1:1 using Pearson's Chi-square test performed using $\mathrm{R}$ 3.4.2 (R Core Team, 2020).

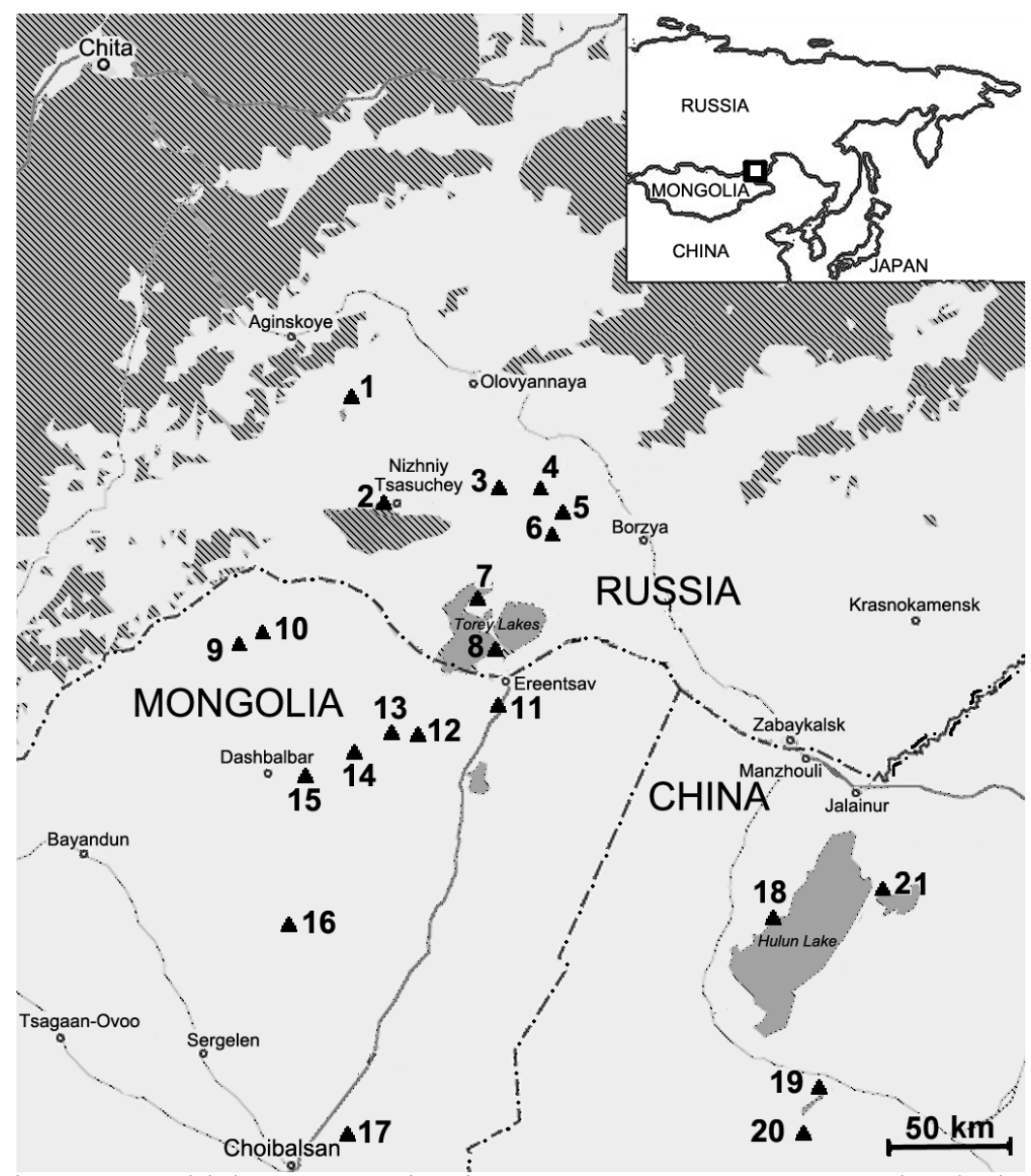

Fig. 1. Map of the Daurian steppe with bat capture sites in 2008-2019. Forest areas are hatched. Numeration of the study sites is defined in Table 1. 
Table 1. Number and percentage (in brackets) of bats at each site in the Daurian steppe

\begin{tabular}{|c|c|c|c|c|c|c|c|}
\hline № & Location & 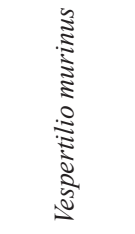 & 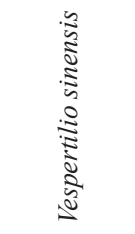 & 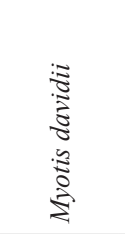 & 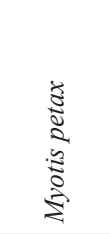 & 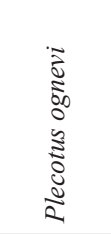 & 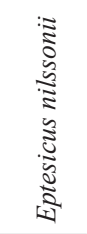 \\
\hline \multicolumn{8}{|c|}{ Russia, Zabaikalsky Krai } \\
\hline 1 & Aginsky district, cliffs by the lake Ulin. $50.9081^{\circ} \mathrm{N}, 114.9036^{\circ} \mathrm{E}$ & $2(5.4)$ & $3(8.1)$ & $32(86.5)$ & - & - & - \\
\hline 2 & $\begin{array}{l}\text { Ononsky district, River Onon bank near the car bridge: rocks, concrete bridge, buildings in } \\
\text { the villages of Verhniy Tsasuchey and Nizhniy Tsasuchey. } 50.5244^{\circ} \mathrm{N}, 115.0533^{\circ} \mathrm{E}\end{array}$ & $8(27.6)$ & $18(62.1)$ & - & - & $2(6.9)$ & $1(3.4)$ \\
\hline 3 & $\begin{array}{l}\text { Aginsky district, right bank of the River Onon, } 6 \mathrm{~km} \text { northeast of the village of Ust- } \\
\text { Borzya: Kheetey cave (Sukhaya). } 50.6431^{\circ} \mathrm{N}, 115.7661^{\circ} \mathrm{E}\end{array}$ & - & - & - & - & $1(100)$ & - \\
\hline 4 & $\begin{array}{l}\text { Olovyanninsky district, north of Adun-Chelon mountains: country road, several concrete } \\
\text { small bridges. } 50.5789^{\circ} \mathrm{N}, 115.9552^{\circ} \mathrm{E}\end{array}$ & $17(68.0)$ & $8(32.0)$ & - & - & - & - \\
\hline 5 & $\begin{array}{l}\text { The juncture of Olovyanninsky, Borzinsky and Ononsky disticts: cliffs of the Adun- } \\
\text { Chelon mountains, forest-steppe. } 50.4900^{\circ} \mathrm{N}, 116.0670^{\circ} \mathrm{E}\end{array}$ & $8(34.8)$ & $5(21.7)$ & $2(8.7)$ & - & $8(34.8)$ & - \\
\hline 6 & $\begin{array}{l}\text { Ononsky district, southwest of Adun-Chelon mountains: ruined concrete building. } \\
50.3706^{\circ} \mathrm{N}, 115.9428^{\circ} \mathrm{E}\end{array}$ & $7(35.0)$ & $13(65.0)$ & - & - & - & - \\
\hline 7 & $\begin{array}{l}\text { Ononsky district, the eastern shore of the Lake Barun-Torey, Myrgen Peninsula: wooden } \\
\text { barn. } 50.1739^{\circ} \mathrm{N}, 115.5678^{\circ} \mathrm{E}\end{array}$ & $2(100)$ & - & - & - & - & - \\
\hline 8 & $\begin{array}{l}\text { Borzinsky district, the southwestern shore of the Lake Zun-Torey: Utochi research station } \\
\text { buildings. } 49.9997^{\circ} \mathrm{N}, 115.7311^{\circ} \mathrm{E}\end{array}$ & $243(86.8)$ & $37(13.2)$ & - & - & - & - \\
\hline \multicolumn{8}{|c|}{$\begin{array}{ll} & \text { Mongolia, Dornod Aimag } \\
\end{array}$} \\
\hline 9 & $\begin{array}{l}\text { The right bank of the River Duchiyn-Gol, Erhat-Ula mountain: cracks in the rock. } \\
50.0431^{\circ} \mathrm{N}, 114.1991^{\circ} \mathrm{E}\end{array}$ & - & - & $1(100)$ & - & - & - \\
\hline 10 & $\begin{array}{l}\text { The right bank of the River Duchiyn-Gol: coastal cliffs opposite the mountain Gatsa. } \\
50.0866^{\circ} \mathrm{N}, 114.2875^{\circ} \mathrm{E}\end{array}$ & - & - & $1(100)$ & - & - & - \\
\hline & $\begin{array}{l}10 \mathrm{~km} \text { south of the Erenzav station: the railroad bridge over the River Teliyn-Gol. } \\
49.8089^{\circ} \mathrm{N}, 115.7231^{\circ} \mathrm{E}\end{array}$ & - & $39(100)$ & - & - & - & - \\
\hline & $\begin{array}{l}\text { The right bank of the River Uldza opposite lake Galutin-Nuur: rocks. } 49.7064^{\circ} \mathrm{N} \text {, } \\
115.3281^{\circ} \mathrm{E}\end{array}$ & $3(15.0)$ & - & $17(85.0)$ & - & - & - \\
\hline & The shore of the Lake Galutin-Nuur: wooden barn. $49.7322^{\circ} \mathrm{N}, 115.3111^{\circ} \mathrm{E}$ & - & $55(100)$ & - & - & - & - \\
\hline & $\begin{array}{l}\text { The right bank of the River Uldza, Ile-Turut mountain: rocks and the shepherd farm. } \\
49.6369^{\circ} \mathrm{N}, 114.9447^{\circ} \mathrm{E}\end{array}$ & $1(16.7)$ & - & $5(83.3)$ & - & - & - \\
\hline & $\begin{array}{l}\text { The Lake Shogoy-Tsagan-Nuur (Chuh-Nuur): rocks and the rest station buildings. } \\
49.5256^{\circ} \mathrm{N}, 114.6681^{\circ} \mathrm{E}\end{array}$ & $19(29.2)$ & $6(9.2)$ & $40(61.5)$ & - & - & - \\
\hline & $20 \mathrm{~km}$ northwest the Lake Yakhiyn-Nuur: the rock near the spring. $48.8039^{\circ} \mathrm{N}, 114.2181^{\circ} \mathrm{E}$ & - & - & $2(100)$ & - & - & - \\
\hline & $\begin{array}{l}\text { The left bank of the River Kerulen } 5 \mathrm{~km} \text { downstream of Choibalsan town. } \\
48.1281^{\circ} \mathrm{N}, 114.7167^{\circ} \mathrm{E}\end{array}$ & - & - & - & $10(100)$ & - & - \\
\hline \multicolumn{8}{|c|}{$\begin{array}{ll} & \text { China, Inner Mongolia } \\
\end{array}$} \\
\hline & $\begin{array}{l}\text { The shore of the Lake Hulun-Nuur (Dalay-Nor): coastal cliffs and buildings. } \\
48.9222^{\circ} \mathrm{N}, 117.1083^{\circ} \mathrm{E} ; 48.9033^{\circ} \mathrm{N}, 117.0078^{\circ} \mathrm{E}\end{array}$ & $19(7.1)$ & $222(83.1)$ & $12(4.5)$ & $14(5.2)$ & - & - \\
\hline & The shore of the Lake Wulan-Nuur, Orshun-Gol River basin: buildings. $48.3761^{\circ} \mathrm{N}, 117.5158^{\circ} \mathrm{E}$ & $10(41.7)$ & $13(54.2)$ & $1(4.2)$ & - & - & - \\
\hline & $\begin{array}{l}\text { River Orshun-Gol } 15 \mathrm{~km} \text { upstream the confluence the Lake Wulan-Nuur: concrete car } \\
\text { bridge. } 48.2400^{\circ} \mathrm{N}, 117.6353^{\circ} \mathrm{E}\end{array}$ & - & $54(100)$ & - & - & - & - \\
\hline & The north shore of the New Dalai Lake Bay: coastal cliffs. $49.0919^{\circ} \mathrm{N}, 117.8572^{\circ} \mathrm{E}$ & $14(27.5)$ & $6(11.8)$ & $31(60.8)$ & - & - & - \\
\hline
\end{tabular}

\section{Results}

\section{Bat records}

A total of 1013 bat specimens were captured. They belonged to four genera and six species (Table 1, Fig. 2), including 479 individuals of Vespertilio sinensis, 353 individuals of $V$. murinus, 145 individuals of Myotis davidii, 24 individuals of $M$. petax, 11 individuals of Plecotus ognevi, and one individual of Eptesicus nilssonii.

\section{Summer shelters of bats}

The natural shelters of bats in the Daurian steppe are composed of cracks and niches in the rocks, heaps and scree of stones. Human constructions in the steppe are also important for bats. The results of Chi-square test are demonstrated in Table 2. A significant positive association of Myotis davidii records with fresh water sources and rocks was found. A significant negative association of $M$. davidii and human constructions was found too. Vespertilio species are less choosy in selecting the summer shelters. A positive (but statistically insignificant) relationship between both Vespertilio species and the presence of buildings was demonstrated. 


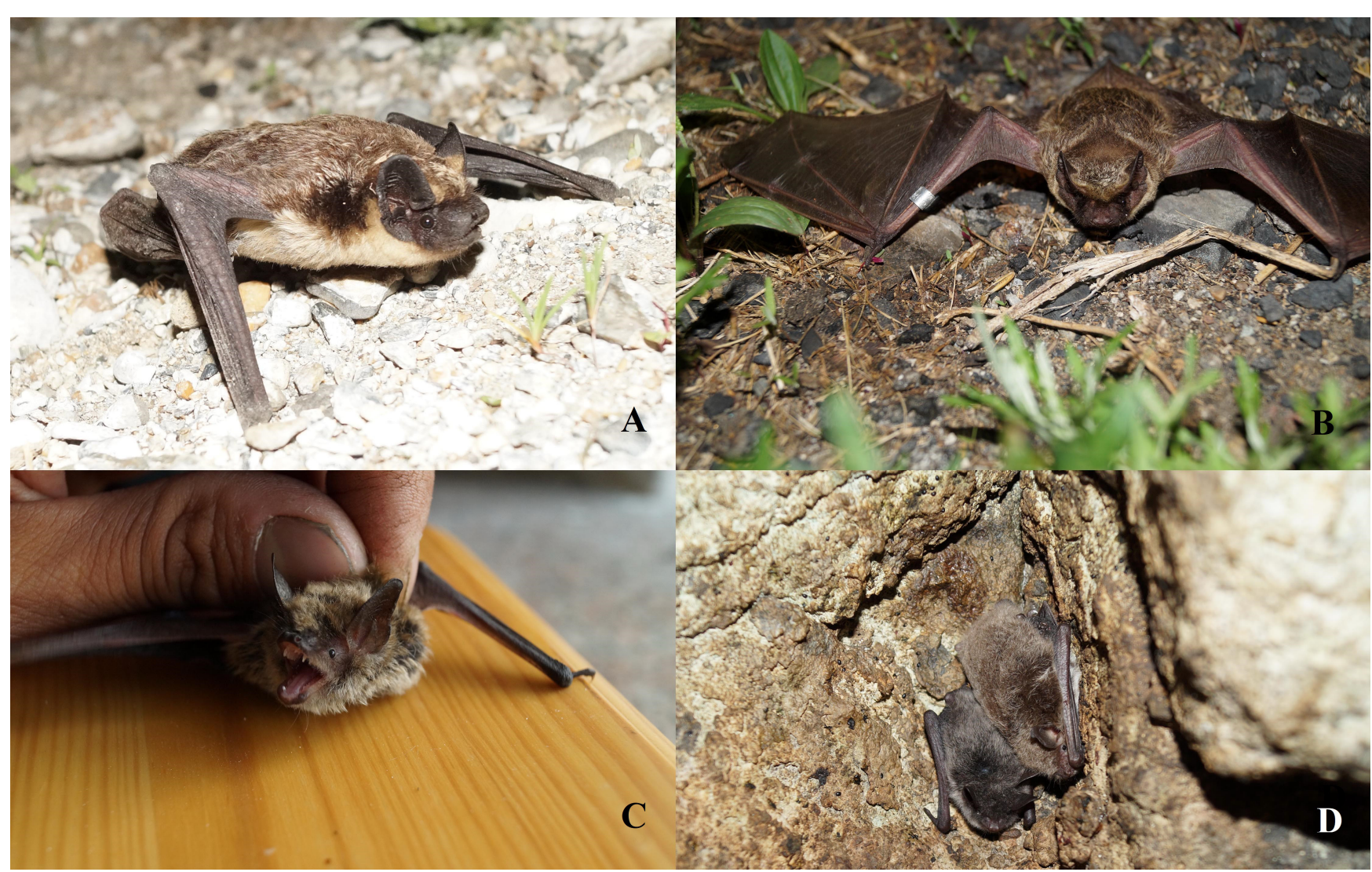

Fig. 2. Bat species of the Daurian steppe. Designations: A - Vespertilio murinus on Torey lakes (Russia); B - band tagged Vespertilio sinensis on Torey lakes (Russia); C - captured Myotis davidii on Lake Hulun-Nuur (China); D - female and young Myotis petax on Lake Hulun-Nuur (China).

Table 2. The relationships between the most common Daurian steppe bat species and most important environment elements in a 500-m buffer around the recorded location

\begin{tabular}{|l|c|c|c|}
\hline \multirow{2}{*}{ Environment elements } & \multicolumn{2}{|c|}{ Species } \\
\cline { 2 - 4 } & Vespertilio murinus & Vespertilio sinensis & Myotis davidii \\
\hline \multirow{2}{*}{ Buildings } & + & + & - \\
& $1.8357 / 0.1755$ & $2.6751 / 0.1019$ & $\mathbf{5 . 6 0 7 6 / 0 . 0 1 7 9}$ \\
\hline \multirow{2}{*}{ Rocks } & - & - & + \\
\hline \multirow{2}{*}{ Forest (trees) } & $1.7003 / 0.1923$ & $1.7003 / 0.1923$ & - \\
\hline \multirow{2}{*}{ Open fresh water sources } & $0.4858 / 0.4858$ & + & $0.000 / 1.0000$ \\
\hline
\end{tabular}

Note: Results of Chi-square test (X-squared / p-value); positive (+) and negative (-) correlation. The statistically significant relationships are in bold.

Almost all of the Myotis davidii specimens were found only in natural shelters near fresh water sources. Noteworthy, some $M$. davidii specimens were hiding under the "stone visor» in the Dalai Lake coastal cliffs (China). They sat almost openly in small niches during the day. In scree of flat rock fragments, the brood colonies of $M$. davidii are characteristic of crags in Mongolia. We did not observe this species in the buildings in the Daurian steppe, although previous study confirmed that $M$. davidii dwelled in the building walls on the west shore of Lake Zun-Torey (Rosina \& Kirilyuk, 2000). On the contrary, we found most often the Vespertilio shelters in human buildings: under a covering of walls and roofs, in cracks of concrete bridges and other structures. Vespertilio bats tended to hide in big rock cracks, caves and heaps of stones too. Few summer records of Vespertilio specimens are known in hollows and under the lagged old pines in Tsasushey pine (Pinus sylvestris L.) forest (Russia) (Rosina \& Kirilyuk, 2000; our data).

We have found the Myotis petax shelter only once, deeply hidden in a small cave in Lake Dalai coastal cliffs. Probably Plecotus ognevi bats hides 
in rock cracks of the Adun-Chelon Mountains. Shelters of Eptesicus nilssonii were not found.

\section{Sex ratios}

All of the captured adult Vespertilio sinensis individuals determined by gender and age $(\mathrm{n}=90)$ were females (Table 3 ). The sex ratio of $V$. sinensis juveniles in China was approximately equal. But the sex ratio of $V$. sinensis subadults was femalebiased $\left(\chi^{2}=5.97, \mathrm{p}<0.05\right)$.

In Russia, only one of the 183 adults of Vespertilio murinus was male $\left(\chi^{2}=116.55\right.$, $\mathrm{p}<0.001)$. The sex ratio of $V$. murinus subadults is female-biased, too (no significant difference). We caught adult Myotis davidii males in Russia and Mongolia. Its sex ratio was female-biased $\left(\chi^{2}=46.57, \mathrm{p}<0.001\right)$.

\section{Observation dates}

We have representative data about the three most abundant bat species. The first yearly records of Myotis davidii were in early May. We found this species on 8 May (Lake Shogoy-Tsagan-Nuur, Mongolia) and 13 May (Lake Ulin, Russia). In Mongolia, one bat was found in scree of the stones on the shore of a lake. In Russia, about ten bats were found in the rock crack just a few centimetres from the surface. The bats warmed themselves during the day. The air temperature was not high (about $5^{\circ} \mathrm{C}$ ) but the rock surface was well warmed by the sun. We cannot exclude the possibility of bat wintering in the rock crack deep. It is impossible to find bats in such places in winter. Caves with large colonies of hibernating bats are not known in the Daurian steppe. On 6-7 September, we specifically examined some previously known summer shelters of Myotis davidii in Mongolia, but bats were not found there. We observed this bat species mainly from the last decade of May to mid-August.

The earliest first record of Vespertilio murinus was made on 19-20 May, while the latest first record was on 9-10 June based on 12 years of observation on Torey Lakes (Russia). In Mongolia, the earliest first record of $V$. murinus was on 16 May. We caught this individual together with $M y$ otis davidii on Lake Shogoy-Tsagan-Nuur rocks. Vespertilio sinensis settled in summer shelters later than Vespertilio murinus. In Russia, the earliest first records of $V$. sinensis were in the second half of June. The latest records of Vespertilio sp. were in late August. Single individuals of Vespertilio sp. were observed in early September.

\section{Bat community dynamics}

Since 2013, we have observed an increase in the proportion of Vespertilio sinensis among the captured bats. For example, its percentage was $6.3 \%$ in $2011(\mathrm{n}=16)$, while it was $1.4 \%(\mathrm{n}=73)$ in $2012,24.4 \%(\mathrm{n}=90)$ in $2013,15.1 \%(\mathrm{n}=86)$ in 2014 on Torey lakes (Russia). In 2013, we observed this species for the first time near Lake Ulin (Fig. 1, Table 1). It is the northernmost location of the species in the Eastern Transbaikalia. We found that $V$. sinensis colonies consisted of several to thousands of individuals. All large colonies of $V$. sinensis were single-species ones. In little colonies $V$. sinensis, specimens can live in association with V. murinus. In 2013-2014, in Russia (Torey lakes) we noted displacement of $V$. murinus by $V$. sinensis in small shelters in building. Females of $V$. sinensis arrived from wintering later than $V$. murinus, but settled in the same shelter. In a few days most females of $V$. murinus moved to neighbouring but less comfortable shelters.

Table 3. Number and percentage (in brackets) of male and female bats that were captured in the Daurian steppe in 2008-2019

\begin{tabular}{|c|c|c|c|c|c|c|}
\hline \multirow{2}{*}{ Location } & \multicolumn{2}{|c|}{ adult } & \multicolumn{2}{|c|}{ subadult } & \multicolumn{2}{|c|}{ juvenile } \\
\hline & $\hat{\partial}$ & 우우 & $\hat{\partial \sigma}$ & 우 & $\hat{\partial} \hat{O}$ & q9+ \\
\hline \multicolumn{7}{|c|}{ Vespertilio murinus } \\
\hline All & $1(0.5 \%)$ & $182(99.5 \%)$ & $17(40.5 \%)$ & $25(59.5 \%)$ & - & - \\
\hline \multicolumn{7}{|c|}{ Vespertilio sinensis } \\
\hline All & $0(0 \%)$ & $90(100 \%)$ & $32(32.0 \%)$ & $68(68.0 \%)$ & $66(46.5 \%)$ & $76(53.5 \%)$ \\
\hline \multicolumn{7}{|c|}{ Myotis davidii } \\
\hline China & $0(0 \%)$ & $18(100 \%)$ & $8(53.3 \%)$ & $7(46.7 \%)$ & $0(0 \%)$ & $1(100 \%)$ \\
\hline Mongolia & $1(2.9 \%)$ & $33(97.1 \%)$ & $7(63.6 \%)$ & $4(36.4 \%)$ & - & - \\
\hline Russia & $1(3.1 \%)$ & $31(96.9 \%)$ & - & - & - & - \\
\hline \multicolumn{7}{|c|}{ Myotis petax } \\
\hline Mongolia, China & $2(14.3 \%)$ & $12(85.7 \%)$ & $1(50.0 \%)$ & $1(50.0 \%)$ & $3(37.5 \%)$ & $5(62.5 \%)$ \\
\hline \multicolumn{7}{|c|}{ Plecotus ognevi } \\
\hline Russia & $5(55.6 \%)$ & $4(44.4 \%)$ & $0(0 \%)$ & $1(100 \%)$ & - & - \\
\hline \multicolumn{7}{|c|}{ Eptesicus nilssonii } \\
\hline Russia & $0(0 \%)$ & $1(100 \%)$ & - & - & - & - \\
\hline
\end{tabular}


We did not find changes in the abundance of other bat species during the study period. However, we found differences in the bat communities of Russian Dauria when comparing our data with literature. So, Myotis davidii and M. petax were collected in 1990s in the Torey lakes and its tributary, River Imalka (Daursky State Nature Reserve, Russia) (Nekipelov, 1960; Kruskop \& Borissenko, 1996; Rosina \& Kirilyuk, 2000). In the study period (2008-2019), we could not find Myotis species here, despite a careful search.

\section{Discussion}

Six bat species were registered in the Daurian steppe. Three of them, Vespertilio sinensis, V. murinus and Myotis davidii, were the most abundant and common bat species in the studied region.

Our data confirm that Vespertilio sinensis and $V$. murinus are migrating species living in the region only in the summer period. In Dauria, the populations of these two species are female-biased. We assume that adult males inhabit other areas. In the caves of Mongolia, the hibernating Vespertilio species were not found in winter either (Ariunbold, 2016). Winter presence of (supposedly subadult) $V$. murinus in the Baikal region (Russia) is very rare (Botvinkin et al., 2011). Noteworthy, the female predominance was noted not only among adults but also among subadult Vespertilio, too. To date, we have no explanation for this fact.

Winter records of Myotis davidii are not known in the Russian part of the Dauria region (Botvinkin, 2002; our study). We are not sure whether $M$. $d a$ vidii is a migratory species in the Daurian steppe or not. The summer sex ratio of this species argues in favour of a migration hypothesis. The nearest locations of the hibernated $M$. davidii are known in the caves (Taliin agui, Shar khanan, Tsagaandel) in southern Mongolia (Ariunbold, 2016).

Our findings and literature data reveal the tendency of a northward shift of Vespertilio species ranges. In the southeast Transbaikalia and Mongolia, $V$. sinensis was classified as a rare species. Since 2013, we consider this species as one of the predominant bats in Dauria. In 2000s, V. sinensis was found to the west (Erdenesant, west of Tov Province, Mongolia) of previously known locations in Mongolia (Nyambayar et al., 2010). Similarly, Botvinkin et al. (2011) registered V. murinus near Lake Baikal, i.e. about $100 \mathrm{~km}$ north of the range boundaries known in the XX century. We do not exclude the effect of global increasing temperature on Vespertilio ranges shift. We believe that one of the important reasons of northward range expansion of $V$. sinensis in the study period may be attributed to the reduced number of the large lakes and rivers in the Mongolian part of Dauria. Unlike small species, Vespertilio is more mobile and can settle in shelters located far from water sources. Similarly, Phalacrocorax carbo (Blumenbach, 1798) increased abundantly in the northern periphery of the range as a result of the drying up of lakes in Dauria. This fish-eating species populated the large rivers of Transbaikalia, namely Onon, Shilka, Ingoda (our data), and Lake Baikal (Pyzhjanov \& Pyzhjanova, 2010; Pyzhjanov et al., 2016) in the early XXI century. In the northern (Russian) part of the Daurian steppe, the average annual rainfall and the number of permanent water sources is higher. In addition, the large steppe river, Onon, flows here.

At the same time, records of Myotis petax were rare in the Daurian steppe. The strict reliance on riparian habitats is one of the main ecological factors characterising bats of the «Myotis daubentonii» group (M. daubentonii (Kuhl, 1817) and $M$. petax). Myotis petax forages mostly at water surfaces. In Dauria, many lakes and rivers dried up completely in the early XXI century. For example, Rosina \& Kirilyuk (2000) found Myotis petax near Torey lakes. Yet, we could not find this species at this location in 2008-2019.

Supposedly, Myotis davidii is associated with the large water bodies in a less degree. Nevertheless, all of our $M$. davidii finds were made near fresh water bodies. For this species, the water sources could be smaller, e.g. natural springs or condensates in the rocks. Similarly to Myotis pet$a x$, we could not find $M$. davidii near Torey lakes, despite the fact that in the 1990s M. davidii was a common species there. In Dauria, both the Myotis species settle near fresh water sources: on the lake shores, along rivers and springs. Apparently, these species have left their shelters after drying up of the nearest fresh water bodies.

\section{Conclusions}

Our study reveals a comparatively low bat species diversity in the Daurian steppe during the study period. Comparison with literature data showed the changes in the bat community structure in Daurian steppe over the last decades. We assume that the drying up of water sources affects considerably the occurrence and distribution of bats in the Daurian steppe, which especially concerns small Myotis species. The studied region plays an important role for bat species, as it serves as 
a breeding area for migratory species (Vespertilio murinus, $V$. sinensis, and probably Myotis davidii) whose summer populations in Dauria are femalebiased. We recommend excluding $V$. sinensis from the regional Red Data Book of Zabaikalsky Krai and national Red Book of Mongolia, taking into account that this species is common in the Daurian steppe even under the drought conditions.

\section{Acknowledgements}

We thank Dou Huashan (Hulun Lake Nature Reserve, China) for help in collecting material in China, and two anonymous reviewers for constructive comments on the manuscript.

\section{References}

Adams R.A. 2010. Bat reproduction declines when conditions mimic climate change projections for western North America. Ecology 91(8): 2437-2445. DOI: 10.1890/09-0091.1

Amorim F., Jorge I., Beja P., Rebelo H. 2018. Following the water? Landscape-scale temporal changes in bat spatial distribution in relation to Mediterranean summer drought. Ecology and Evolution 8(11): 5801-5814. DOI: $10.1002 /$ ece 3.4119

Ariunbold J. 2016. Cave bat species in Mongolia. In: International Symposium of Science Museums. South Korea. P. 235-237.

Bazhenov Yu.A. 2013. New data on bats in Daurian steppes. Plecotus et al. 15-16: 59-63. [In Russian]

Botvinkin A.D. 2002. Bats in Baikal region (biology, observation methods, conservation). Irkutsk: Vremya stranstviy. 208 p. [In Russian]

Botvinkin A.D., Ivushkin V.E., Ivushkina L.E. 2011. New findings of the porti-coloured bat in the Baikal Region. Plecotus et al. 14: 55-59. [In Russian]

Boyles J., Cryan P., McCracken G., Kunz T. 2011. Economic Importance of Bats in Agriculture. Science 332(6025): 41-42. DOI: 10.1126/science. 1201366

Golyatina M.A., Vakhnina I.L., Kurganovich K.A. 2018. Dynamics of the number and areas of the water surface of lakes Eastern Transbaikalia. In: Kulagin's readings: technology and technologies of production processes. Chita: Transbaikal State University. P. 120-124. [In Russian]

IUCN. 2020. The IUCN Red List of Threatened Species. Version 2020-2. Available from: https://www.iucnredlist.org

Kirilyuk V.E., Tkachuk T.E., Kirilyuk O.K. 2012. The influence of climate change on habitats and biota in the Dauria. In: Adaptation to climate change in the river basins of Dauria: ecology and water management. Chita: Express publishing house. P. 46-62. [In Russian]

Kruskop S.V., Borissenko A.V. 1996. A new subspecies of Myotis mystacinus (Vespertilionidae, Chiroptera) from East Asia. Acta Theriologica 41(3): 331-335. DOI: 10.4098/AT.arch.96-32

Korine C., Adams R., Russo D., Fisher-Phelps M., Jacobs D. 2016. Bats and Water: Anthropogenic Alterations Threaten Global Bat Populations. In: C. Voigt, T. Kings- ton (Eds.): Bats in the Anthropocene: Conservation of Bats in a Changing World. Cham: Springer. P. 215-241. DOI: 10.1007/978-3-319-25220-9

Kunz T.H., Braun de Torrez E., Bauer D., Lobova T., Fleming T.H. 2011. Ecosystem services provided by bats. Annals of the New York Academy of Sciences 1223(1): 1-38. DOI: 10.1111/j.1749-6632.2011.06004.x

Lundy M., Montgomery I., Russ J. 2010. Climate changelinked range expansion of Nathusius' pipistrelle bat, Pipistrellus nathusii (Keyserling \& Blasius, 1839). Journal of Biogeography 37(12): 2232-2242. DOI: 10.1111/j.1365-2699.2010.02384.x

Luo B., Santana S.E., Pang Y., Wang M., Xiao Y., Feng J. 2019. Wing morphology predicts geographic range size in Vespertilionid bats. Scientific Reports 9(1): 4526. DOI: $10.1038 / \mathrm{s} 41598-019-41125-0$

Mongolian Red Book. Ulaanbaatar: Ministry of Environment and Green Development of Mongolia, 2013. 535 p.

Monhnast D. 2014. Bat Diversity and Conservation in Mongol Daguur SPA Region in the North-Eastern Mongolia. In: Proceedings of the International Conference for the $20^{\text {th }}$ anniversary of the DIPA. Ulaanbaatar: Wildlife Conservation Society. P. 75-77.

Nekipelov N. 1960. Distribution of mammals in Southeastern Transbaikalia and population size of some species. In: Biological Collection of Works. Irkutsk: Irkutsk State University. P. 3-48. [In Russian]

Norberg U., Rayner J. 1987. Ecological morphology and flight in bats (Mammalia; Chiroptera): wing adaptations, flight performance, foraging strategy and echolocation. Philosophical Transactions of the Royal Society of London. Series B, Biological Sciences 316: 337-419. DOI: $10.1098 /$ rstb.1987.0030

Nyambayar B., Ariunbold J., Sukhchuluun G. 2010. A contribution to the bats inhabiting arid steppe habitats in Central Mongolia. Exploration into the Biological Resources of Mongolia 11: 329-340.

Obyazov V. 2012. Climate change and the hydrological regime of rivers and lakes in the Dauria ecoregion. In: $A d$ aptation to climate change in the river basins of Dauria: ecology and water management. Chita: Express publishing house. P. 24-45. [In Russian]

Pyzhjanov S.V., Pyzhjanova M.S. 2010. Modern status of common cormorant at Baikal and Khubsugul (Mongolia). The Bulletin of Irkutsk State University. Series «Biology. Ecology» 1: 60-63. [In Russian]

Pyzhjanov S.V., Pyzhjanova M.S., Tupitsyn I.I. 2016. Problem of big cormorant protection on Baikal in a view of its area natural dynamics. Proceedings of Samara Scientific Centre RAS 2: 182-185. [In Russian]

R Core Team. 2020. $R$ : a language and environment for statistical computing. Vienna, Austria: R Foundation for Statistical Computing. Available from http:// www.r-project.org

Razgour O., Persey M., Shamir U., Korine C. 2018. The role of climate, water and biotic interactions in shaping biodiversity patterns in arid environments across spatial scales. Diversity and Distributions 24(10): 1440-1452. DOI: $10.1111 /$ ddi.12773 
Red Data Book of Zabaikalsky Krai. Animals. Novosibirsk: Novosibirsk Publishing House, 2012. 344 p. [In Russian]

Rosina V.V., Kirilyuk V.E. 2000. Finds of bats in the Daursky State Nature Reserve and in the surrounding areas. Plecotus et al. 3: 108-113. [In Russian]

Sherwin H.A., Montgomery W.I., Lundy M.G. 2013. The impact and implications of climate change for bats. Mammal Review 43(3): 171-182. DOI: 10.1111/j.13652907.2012.00214.x
Sosnina M., Kurganovich K. 2015. Assessment of lake Barun-Torey water surface changes for the period 19762014 using LANDSAT remote sensing data. In: Water resources and water use. Chita: Transbaikal State University. P. 23-31. [In Russian]

Wu J. 2016. Detection and attribution of the effects of climate change on bat distributions over the last 50 years. Climatic Change 134(4): 681-696. DOI: 10.1007/ s10584-015-1543-7

\title{
ЭКОЛОГИЯ РУКОКРЫЛЫХ АРИДНОГО РЕГИОНА (ДАУРСКАЯ СТЕПЬ) НА ПИКЕ ЗАСУХИ
}

\author{
Ю. А. Баженов \\ Институт природных ресурсов, экологии и криологии СО РАН, Россия \\ e-mail:uran238@ngs.ru
}

Рукокрылые (Chiroptera) - наименее изученная группа млекопитающих Даурской степи (Внутренняя Азия: Монголия, Россия и Китай). Мы изучали фауну рукокрылых Даурской степи и некоторые экологические особенности видов летучих мышей в 2008-2019 гг. Мы зарегистрировали шесть видов рукокрылых, среди которых наиболее многочисленны Vespertilio murinus, V. sinensis и Myotis davidii. Myotis davidii предпочитает в качестве убежищ скалы вблизи пресных водных источников. В отличие от рукокрылых рода Vespertilio, M. davidii избегает селиться в постройках человека. Виды Vespertilio могут обитать гораздо дальше от источников воды по сравнению с M. davidii. Соотношение полов среди отловленных особей $M$. davidii, Vespertilio murinus и V. sinensis смещено в сторону преобладания самок. Это предполагает, что данные виды, скорее всего, не зимуют в Даурской степи. Наши результаты показывают важную роль региона для этих мигрирующих видов рукокрылых как зоны размножения. В начале XXI в. многие озера и реки Даурии пересохли полностью или частично. В российской части Даурской степи мы наблюдали увеличение популяции $V$. sinensis и уменьшение популяций Myotis davidii и M. petax. Мы предполагаем, что изменения в сообществе рукокрылых являются следствием сокращения числа водоемов в Даурии, особенно в ее монгольской части (аймак Дорнод).

Ключевые слова: засушливый период, изменения климата, Монголия, расширение ареала, соотношение полов 